\title{
THE ABUNDANCE, DIVERSITY, AND THE DENSITY OF MOLLUSKS IN \\ TUTUWOTO MANGROVE AREA OF ANGGREK DISTRICT, NORTH GORONTALO REGENCY, GORONTALO, INDONESIA
}

\author{
Dewi Wahyuni K. Baderan', Marini Susanti Hamidun², Farid S M ${ }^{3}$ \\ 1,2,3 Department of Biology, Faculty of Mathematics and Natural Sciences, Universitas Negeri \\ Gorontalo, J1. Jendral Sudirman No. 6 Gorontalo City 96128, Gorontalo Province, Indonesia. \\ Tel./Fax. +0435-821752 \\ e-mail: dewi.baderan@ung.ac.id
}

\begin{abstract}
The aim of the current study is to calculate the value of the abundance, diversity, and the density of phyla mollusks in the Tutuwoto mangrove area of Anggrek District. The survey method is used in this study as a method, which means that it collects the data directly at the research area. The observations were carried out under mangrove stands. The area of the observation plot is $5 \mathrm{~m} \times 5 \mathrm{~m}$. Phylum mollusks collected at the study site were counted by the number of individuals, abundance, diversity, and density of the types of each species. Sanon-Wienner formula is used to calculate the species diversity, Brower formula is used to calculate the density, and Odum formula is used to calculate the abundance of the species. The findings show that it is found that the reasearch about phylum mollusks in Tutuwoto mangrove area consisted of 6 (six) types namely Terebralia sulcata, Terebralia palustris, Nerita articulate, Hexaplex trunculus, Anadara granosa, and Mactra grandis. Based on the calculation of the abundance, diversity, and density of the mollusks phylum at the research site, there are several types that have the highest value. In the gastropod class, Nerita articulata has the highest score with an abundance of $30.41 \%$, diversity of 0.36 , and density of 0.17 ind / $\mathrm{m} 2$, followed by Terebralia sulcata with an abundance of $28.07 \%$, diversity 0.36 , and density of 0.16 ind $/ \mathrm{m} 2$. However, the lowest is owned by Terebralia palustris with an abundance value of $17.54 \%$, diversity of 0.31 , and density of $0.10 \mathrm{ind} / \mathrm{m} 2$. The values of abundance, diversity, and density in the bivalve class have different values. The type of Anadara granosa has an abundance value of $53.06 \%$, diversity of 0.34 , and density of 0.08 ind / $\mathrm{m} 2$ while Mactra grandis has an abundance value of $46.94 \%$, diversity of 0.36 , and density of 0.07 ind $/ \mathrm{m} 2$. Based on the predetermined criteria of the Gastropod class, it has the abundance in many categories, exceptional of Terebralia palustris which has sufficient criteria.
\end{abstract}

Keywords: Mangrove, Mollusks, Tutuwoto

\section{A. INTRODUCTION}

Mangroves are categorized as the types of plants that are often found on muddy coasts and river estuaries. The mangrove ecosystem is a tropical coastal vegetation community consisting of several species that develop and are able to grow in muddy coastal tidal areas (Bengen, 2001). Lisna et al., (2017) states that mangrove ecosystems are the main ecosystems supporting life that are important in coastal and marine areas. Therefore, it can be concluded that the mangrove ecosystem is a coastal ecosystem that consists of a group 
of endemic coastal species that function as supporters of coastal life.

Moreover, mangrove forests are one of the natural ecosystems that have high ecological value. The ecological functions of mangrove ecosystems include protecting the coast from wind attacks, currents, and waves from the sea, habitats (living quarters), feeding ground, nursery, and enlargement, and spawning ground for aquatic biota including, shrimp, crabs, fish and shellfish (mollusks). The animals belonging to the phylum of mollusks are one of the non-fish biological resources that have high diversity. Some mollusks animals can live on land, fresh waters, and marine waters. Mollusks associate with the mangrove ecosystem as a habitat for the living, sheltering, spawning and also as a food supply area that supports the growth of these mollusks. According to Odum (1996), mollusks play a role as a food chain detritus feeder in the nutrient cycle because mollusks are located as early decomposers that work by chopping mangrove leaves into small parts and then being followed by smaller organisms namely microorganisms so that its presence is very influential in the food chain. The existence and abundance of mollusks in the mangrove ecosystem is largely determined by mangrove vegetation. The composition and diversity of mollusks are influenced by the local environment such as food availability, predation, and competition. In addition, the pressure and changes in the environment can affect the number of types and differences in structure (Sari et al, 2012).

Mangrove forests often get stress due to irresponsible management that will cause the pressure that can lead to changes in the ecosystem, both affecting the physical, chemical, and biological conditions of the mangrove forest itself. The damage to the mangrove ecosystem occurs because of the influence of two factors, namely natural and human factors. The natural factors that cause mangrove damage are the occurrence of storms, global warming and the rise of sea level. Moreover, the damage caused by human factors includes the existence of irresponsible logging, uncontrolled land conversion and the use of unsynchronized coastal areas between one region and etc.

The forests of mangrove in Tutuwoto Village of Anggrek District, North Gorontalo Regency are located along the coast with an area of 11 hectares (KPH North Gorontalo, 2010). The mangrove area of Tutuwoto has experienced a reduction in area, the local community uses mangrove areas as residential and agricultural areas, and uses mangrove wood as a material for making houses and livestock pens. 
The lower understanding of the community about mangrove forests that are used to fulfill their needs by themselves, enable interdependence to overuse the actions that have a detrimental effect resulting in habitat degradation without regard to sustainability and considerable benefits for ecosystem productivity. These activities will affect the decreasing density of mangroves which results in less leaf litter production and reduced decomposition process as the supply of energy sources for living resources inside, especially mangrove crabs, mollusks, shrimp and fish that feed in the mangrove ecosystem. The changes caused by human activities such as increased logging of mangrove forests can cause a decrease in the quantitative value of mangrove forests. A study that aims to determine the value of diversity, abundance and density of mollusks needs to be done. So that the role of mangrove forests as a supporter and provider of services for the survival of the fauna inside is maintained.

\section{B. MATERIALS AND METHODS}

The current research was carried out in the Tutuwoto mangrove area of Anggrek District, North Gorontalo Regency, Gorontalo Province. It was also conducted for 3 (three) months, starting from AprilJune 2018. The timeline of the current research included the preparation of the research proposal, data collection, data analysis of the research to the report of research results.
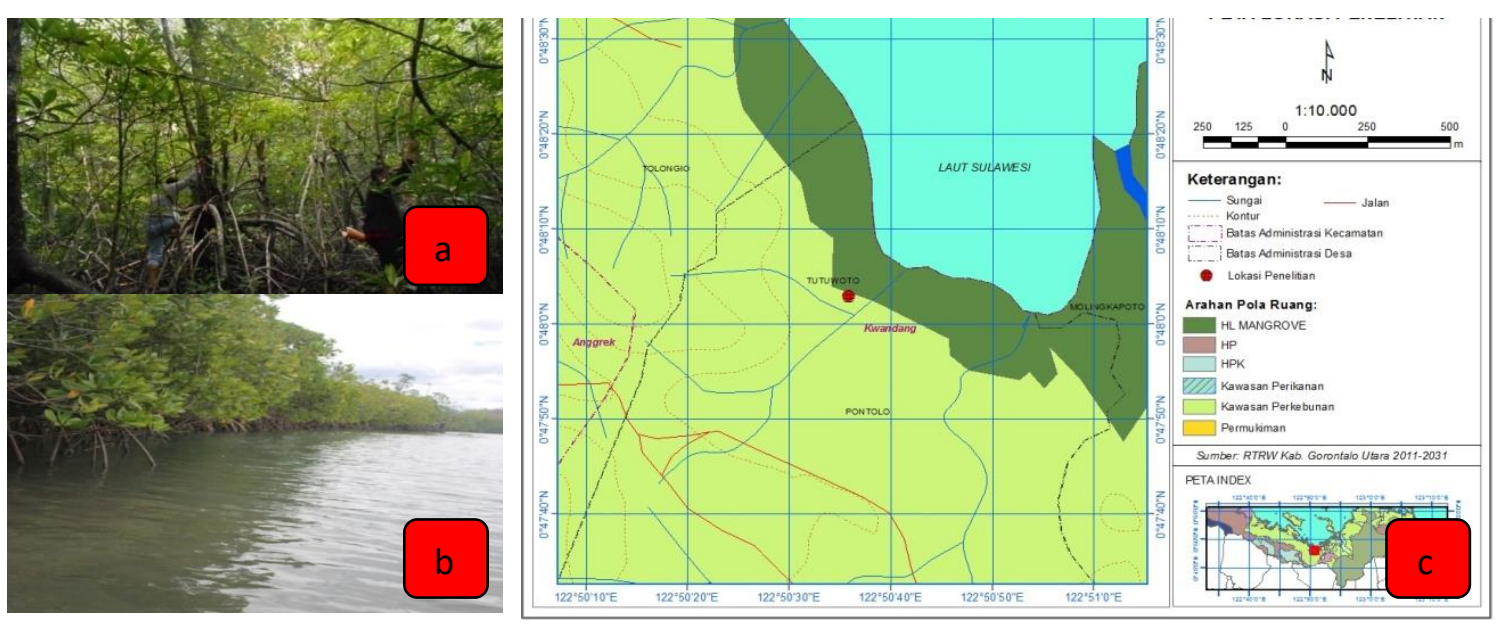

Figure 1. The research site, (fig. a) The condition of the mangrove, (fig. b) the outermost condition of mangrove, (fig. c) the adminisrative map of the research site.

A survey is used as a method in this study, which is a method of collecting data directly at the research site. The aquatic fauna belonging to the phyla of mollusks is done by direct observation. The observation is carried out under mangrove stands. The 
area of the observation is $5 \mathrm{~m} \times 5 \mathrm{~m}$. The fauna found in the next observation plot is counted the number of individuals and is recorded in the observation book. Furthermore, the aquatic fauna collected at the research site is calculated by the number of individuals, abundance, diversity, and density of each species.

The calculation of the species diversity uses a Sannon-wienner formula:

$\mathbf{H}^{\prime}=-\sum \boldsymbol{P i} \ln \boldsymbol{P i} \quad$ where $p i=(n i / N)$

Where:

$$
\begin{array}{ll}
\mathrm{H}^{\prime} & =\text { The Diversity Index } \\
n i & =\sum \text { The individual of each } \\
& \text { species } \\
\mathrm{N} & \sum \text { the total individual of all } \\
& \text { species }
\end{array}
$$

Criteria : Odum, 1996

$$
\begin{aligned}
& \mathrm{H}^{\prime}<1=\text { Low diversity } \\
& 1<\mathrm{H}^{\prime}<3=\text { Medium diversity } \\
& \mathrm{H}^{\prime}>3=\text { High diversity }
\end{aligned}
$$

The calculation of the density uses Brower et al., 1990 formula:

$D=\frac{\mathrm{Ni}}{\mathrm{A}} \times 100 \%$

Where:

$$
\begin{array}{ll}
\mathrm{D} & =\text { Biota density }\left(\mathrm{ind} / \mathrm{m}^{2}\right) \\
\mathrm{Ni} & =\text { The number of individuals } \\
\mathrm{A} & =
\end{array}
$$

By obtaining the $\mathrm{D}$ value, it can be made the classification of each species by referring to the following dominance criteria (Jorgensen):

Criteria:

D $>5 \%$, Dominant category

$\mathrm{D}=2-5 \%$, sub-dominant
$\mathrm{D}<5 \%$, non-dominant category

The abundance of each species is calculated using Odum formula (1996), as follows:

$\boldsymbol{K}$

$=\frac{\text { the number of the individual species } i}{\text { the number of all individuals of the species }} \times 100 \%$

By taking the criteria of the abundance by Michael, (1995) as follows:

$\begin{array}{ll}0 & =\text { none } \\ 1-10 & =\text { less } \\ 11-20 & =\text { enough } \\ >20 & =\text { many }\end{array}$

\section{RESULTS AND DISCUSSION}

\section{Results}

Macintosh et al (2002) stated that mollusks are the organism that has an important role in ecological functions in the mangrove ecosystems, namely as bioindicators in aquatic ecosystems. The group mollusks mangrove as part of the mangrove forest ecosystem has an important role which directly or indirectly supports the ecological functions of the mangrove forests.

Based on the research results about mollusks, it is found that there are six (6) types of mollusks found in the Tutuwoto mangrove area namely Terebralia sulcata, Terebralia palustris, Nerita articulate, Hexaplex trunculus, Anadara granosa, and Mactra grandis. The classification of each species can be seen in the table 1 below, moreover, the morfology form is presented in the Figure 2. 
Table 1. The Classification of Mollusks Phylum Found in Tutuwoto Mangrove Area

\begin{tabular}{|c|c|c|c|c|c|}
\hline PHYLUM & CLASS & ORDO & FAMILY & GENUS & SPECIES \\
\hline \multirow{4}{*}{ Mollusks } & \multirow{3}{*}{ Gastropods } & Caenogastropoda & Potamididae & Terebralia & Terebralia sulcata \\
\cline { 3 - 6 } & & Neritimorpha & Neritidae & Nerita & Nerita articulata \\
\cline { 3 - 6 } & & Hypsogastropoda & Huricidae & Hexaplex & Hexaplex trunculus \\
\cline { 3 - 6 } & \multirow{3}{*}{ Bivalves } & Arcoida & Arcidae & Anadara & Anadara granosa \\
\cline { 3 - 6 } & & Veneroidae & Mactridae & Mactra & Mactra grandis \\
\hline
\end{tabular}
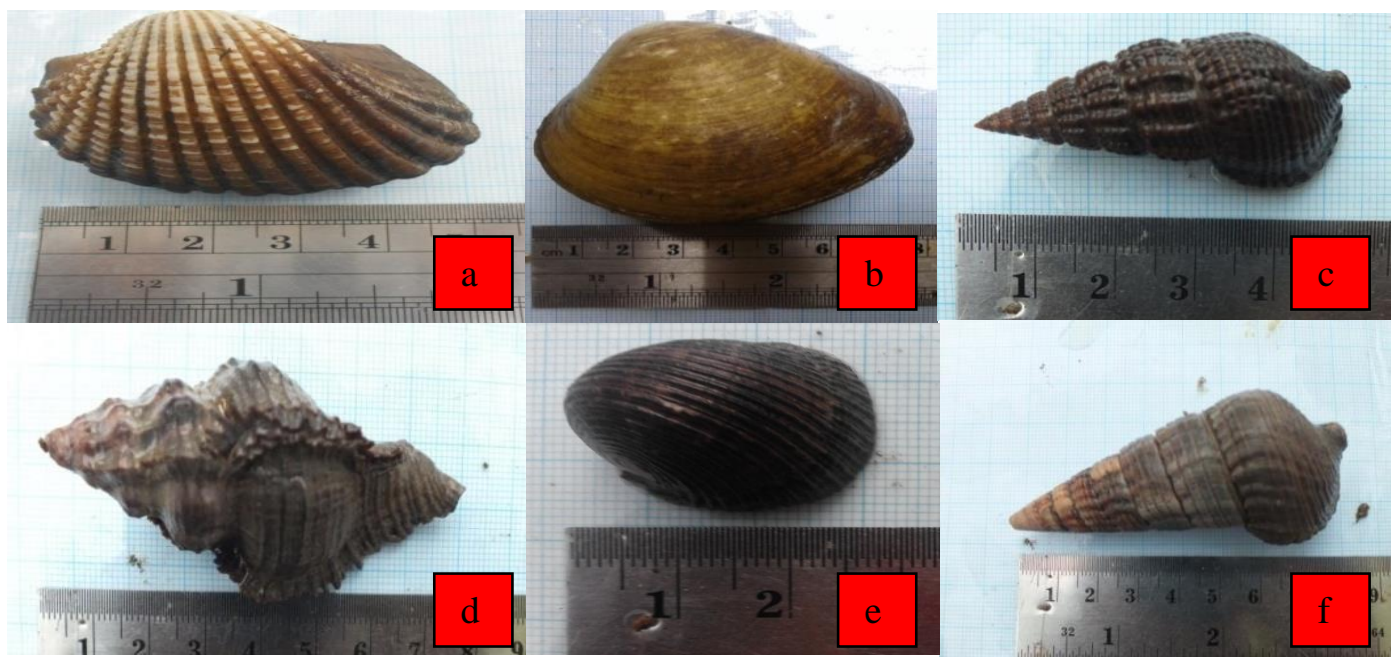

Figure 2. The Morphology Form of Mollusk Phylum Found in the Research site (a)Anadara granosa, (b)Mactra grandis, (c)Terebralia sulcata, (d)Hexaplex trunculus, (e)Nerita articulate (f)Terebralia palustris

\section{The Abundance (K) Mollusk Phylum}

The abundance is the number of the individuals in the particular site in a community. The index value of the abundance at the research site is presented in Figure 3.

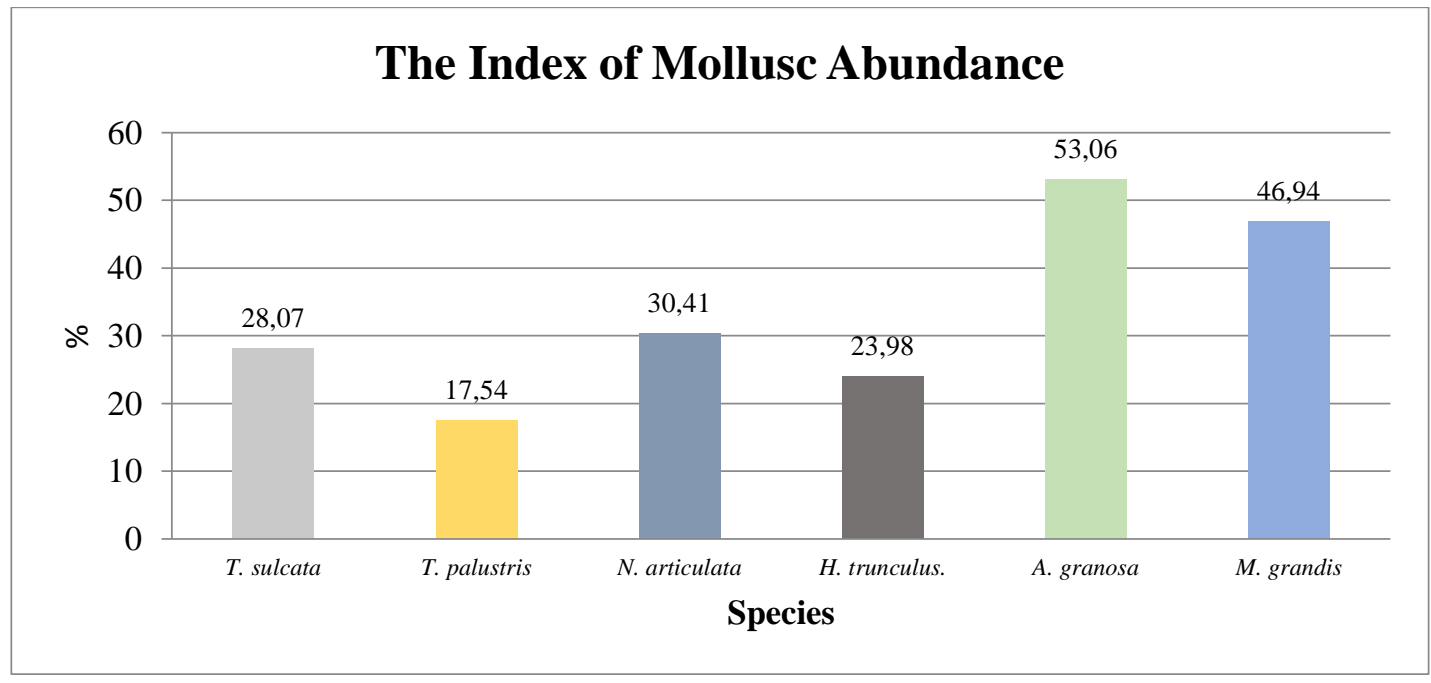

Figure 3. The Abundance Index of Mollusk at the Research Site 
The highest index of abundance is owned by Anadara granosa with a value of $53.06 \%$. The type of Anadara granosa (blood clams) is found in the study sites because it is associated with muddy substrate conditions. Latifah (2011) emphasizes that blood clams are non-fauna, which is alive by immersing themselves under the surface of the mud. The blood clams are more commonly found in areas farther away from river estuaries because river estuaries are the sites most affected by pollutants and fisheries that can exploit shellfish excessively (Intan et al, 2012). This condition is in line with the conditions at the research site whose substrate has characteristics that are muddy and far from the river mouth. Therefore, this type dominates the area.

\section{The Diversit (H') Mollusk Phylum}

The diversity is the total number of species in a particular area or it is also interpreted as the number of species contained in an area between the total number of individuals of the species present in a community. Wahyuni et all, (2017) states that a community has high diversity if all species have relatively the same or almost the same abundance, besides, there is no large dominance so that the diversity value in the study location reflects each species that spread relatively in equal numbers. The diversity index at the research site is presented in Figure 4

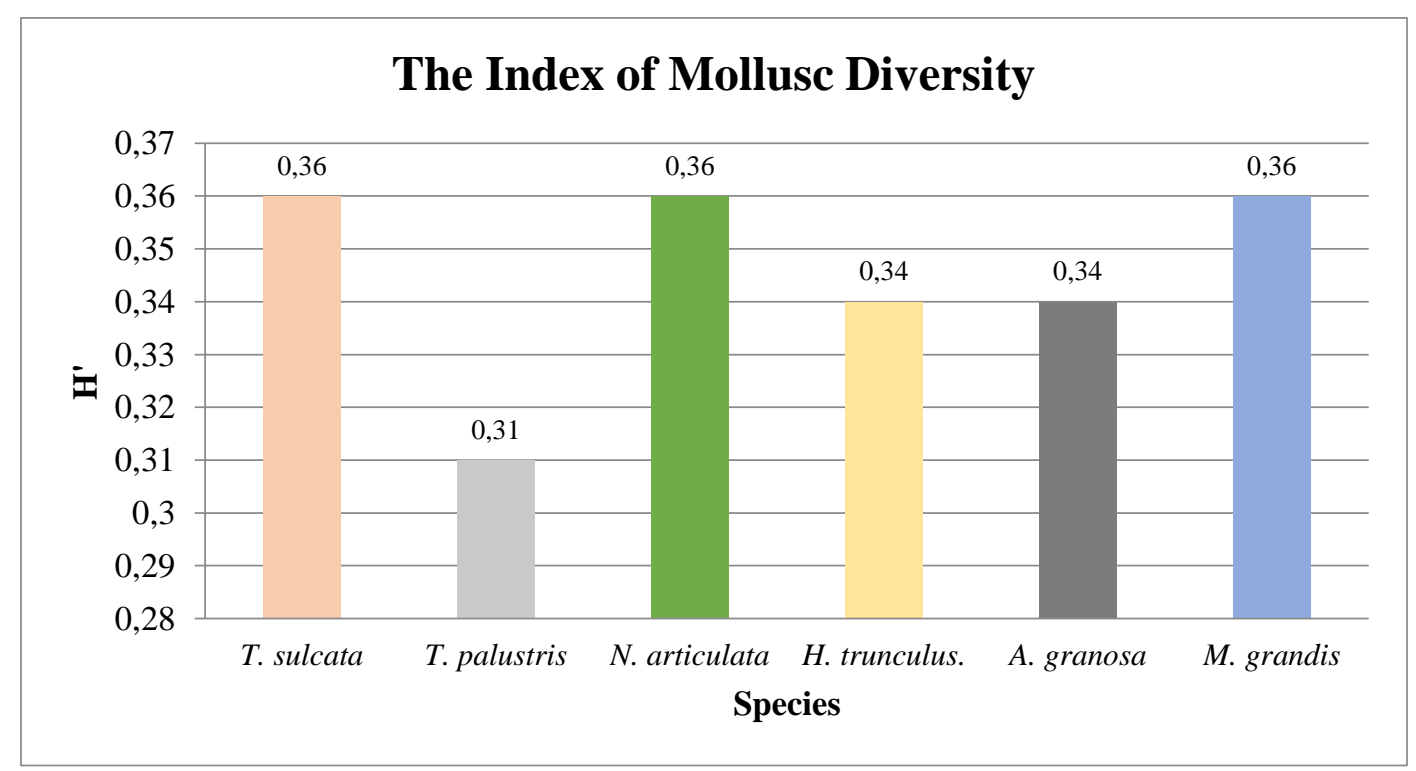

Figure 4. The index of Mollusk Diversity at the Research Site

The results of the calculation of Shannon winner diversity about the total index of mollusk diversity in the study location are 2.07. This shows that the spread of individual numbers per species and community instability is classified as 
moderate. The diversity in research locations in dominance by species Terebralia sulcata, Nerita articulate and Anadara granosa with the diversity value (H') 0.36. These three types dominate the area because they are related to habitat, and the way of life of each type. Nerita articulate and Terebralia sulcata types generally live in groups and are often found attached to the roots, stems, leaves, rocks and wood weathering. This is in line with the statement by Nontji A. (2006), he explains that Nerita articulate species is generally found in the groups with diverse populations. This community can be found in the supralitoral area with the characteristic of sticking, both in the roots, stems and leaves of the vegetation that grows in the area as a form of migration due to the high sea level. The foraging activities in this species are active at night and when the condition of the water is not in tidal wave conditions because of its nature as a scavenger. On the other hand, Mactra grandis breeds and lives in areas that have muddy sand substrates.

\section{The Density (D) Mollusk Phylum}

The density results of the Molusca phylum calculation at the location of the study show that there are several types that have the highest value. Anadara granosa type has the highest value of $53.1 \%$ and followed by Mactra grandis of $46.0 \%$. The density index of mollusk at the research site is presented in Figure 5.

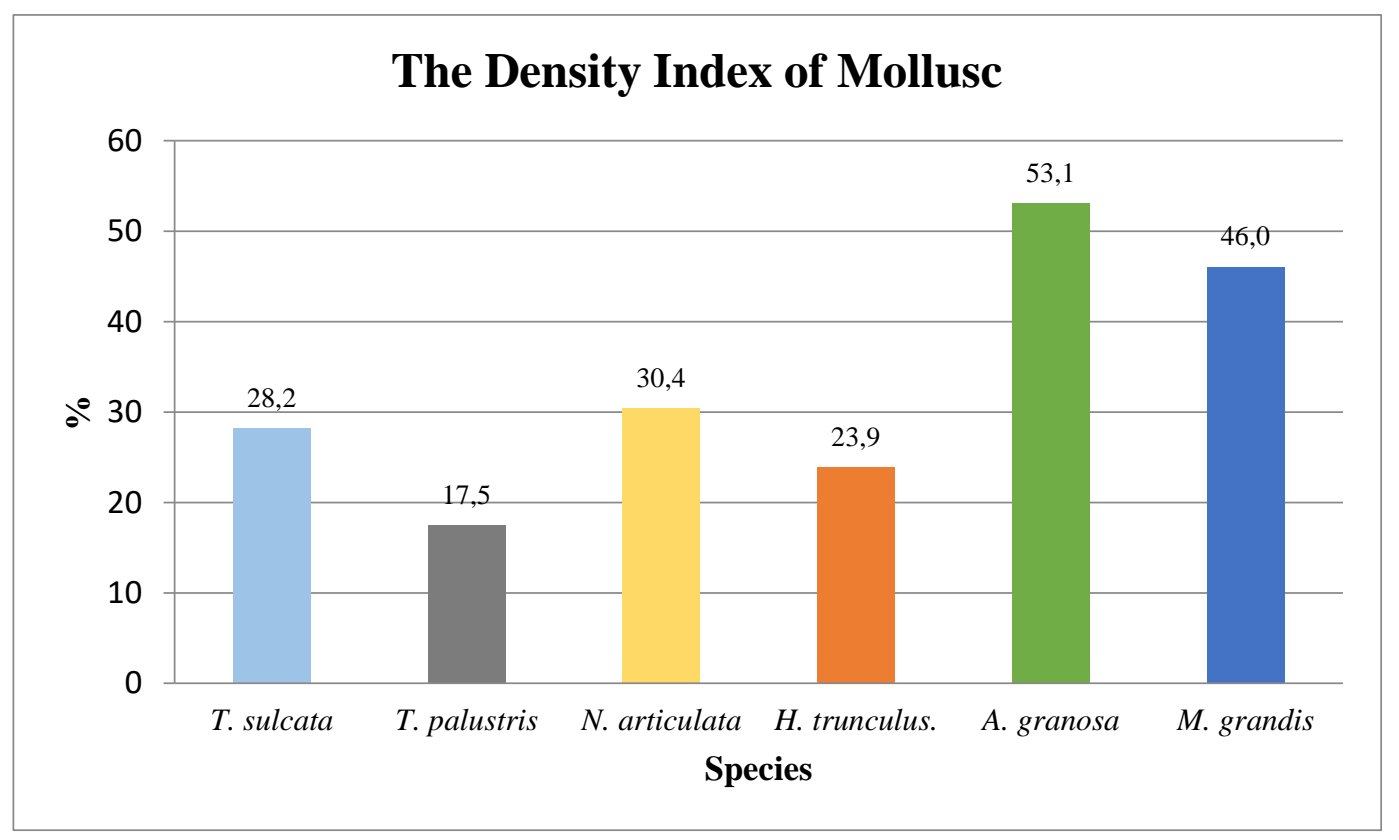

Figure 5. The Density Index of Mollusk at the Research Site

Both types are included in the bivalve class. The height of these two types is related to the place and way of life. The blood clams of Anadara granosa and 
mactra grandis grow well in calm waters, especially in muddy bays that are $46-76 \mathrm{~cm}$ or thicker. The high value is thought to be related to the substrate where they live and look for food and also their tolerance to the extreme environment. This can be seen in Bivalve life preferences in sandy mud or mud habitat in the form of gathering and spreading (Intan, et al., 2014).

\section{The Enviromental Parameters at the Research Site}

The environmental factors have a very important role in supporting the mollusks life. Based on the measurement of environmental factors at the research location, the environmental temperature results are ranged from $27-28^{\circ} \mathrm{C}$, generally mollusks are able to adapt to varying temperatures, that is from $0{ }^{\circ} \mathrm{C}$ to $48.6{ }^{\circ} \mathrm{C}$ and is active at a temperature range of $5{ }^{\circ} \mathrm{C}$ - $38^{\circ} \mathrm{C}$ (Wahyuni et al, 2017). For the details, the results of measuring environmental parameters are presented in Table 2.

Table 2. The results of measuring environmental parameters at the research site

\begin{tabular}{|c|c|c|c|c|c|c|}
\hline \multirow[t]{3}{*}{ Week } & \multicolumn{6}{|c|}{ Environmental factor } \\
\hline & Temperature & \multirow{2}{*}{$\begin{array}{c}\text { Humidity } \\
(\%)\end{array}$} & \multirow[t]{2}{*}{ Soil ph } & \multirow{2}{*}{$\begin{array}{c}\text { Dissolved } \\
\text { oxygen }(\mathrm{mg} / \mathrm{l})\end{array}$} & \multirow{2}{*}{$\begin{array}{c}\text { Water } \\
\text { temperature } \\
\text { ror }\end{array}$} & \multirow[t]{2}{*}{ Salinity (ppt) } \\
\hline & $\left({ }^{\circ} \mathrm{C}\right)$ & & & & & \\
\hline I & 27 & 75 & 6,6 & 2,24 & 28,32 & 23.76 \\
\hline II & 28 & 68 & 6,6 & 2,22 & 28,42 & 24,17 \\
\hline III & 27 & 74 & 6,6 & 2,23 & 28,23 & 23,54 \\
\hline IV & 28 & 73 & 6,6 & 2,24 & 28,33 & 23,42 \\
\hline
\end{tabular}

The observations of salinity at the study site are still quite normal in supporting the life of Mollusks, which ranged from $23.4224-24.17 \%$ because of the range of normal salinity values for mollusk life, which is ranged from 575 - 75 $\%$. Most Mollusk like the $\mathrm{pH}$ value around $7.0-8.5$ and the $\mathrm{pH}$ at the research location is at 6.6. Dissolved oxygen ranges from 2.22-2.24, water temperature 28.2328.42 oC. Humidity ranges from $68-75 \%$,

\section{Discussion}

The animals that live on the bottom of the water are macrozoobenthos. Macrozoobenthos is one of the most important groups in aquatic ecosystems due to its role as a key organism in the food web. Furthermore, the level of diversity found in the aquatic environment can be used as an indicator of pollution. Fitriyani et al., (2016) emphasizes that macrozoobenthos is included in the initial decomposer which plays a role in chopping 
the remnants of leaves that are reissued into feces then followed by bacteria or fungi that convert organic matter into protein and carbohydrates. The organic material is the most important contribution of mangrove forests to the ecosystem through litter avalanches that fall into the forest floor. The litter will be utilized by macrozoobenthos as an energy source and will be broken down again by micro-fauna into nutrients that help mangrove growth.

Mollusks are categorized as one organism that has an important role in the ecological function of the mangrove ecosystem. As for those belonging to the Mollusk group is phylum makrozoobenthos namely gastropod and bivalve which can be used as bio-indicators in aquatic ecosystems (Macintosh et al, 2002). Mollusks found at the research site are Terebralia sulcata, Terebralia palustris, Nerita articulate, Hexaplex trunculus, Anadara granosa, and Mactra grandis. The group of mangrove mollusk as part of the mangrove forest ecosystem has an important role that directly or indirectly supports the ecological functions of mangrove forests. Some mollusk species such as members of the Potamididae, Neritidae, and Carithidae are species that make mangroves their habitat (Arbi, 2008).

Moreover, mollusks have the ability to adapt well to the mangrove environment, survived by crawling and attaching the body to the substrate. Mollusks also have good body resistance and shell adaptation, so they are able to survive compared to other classes (Dali, 2018). Based on the calculation of the value of abundance, diversity, and density of aquatic fauna in the mollusk class in the study location are in the dominance of the species Nerita articulate (gastropod) and Anadara granosa (Pelecypoda). Both of these types dominate the area because they are related to habitat and the way of life of each type. Nerita articulate types generally live in groups and are often found sticking to the roots, stems, leaves, rocks and wood weathering. This is in line with the statement of Nontji A. (2006) who explains that Nerita articulate species are generally found in groups with diverse populations. In the supralitoral area, this community can be found with the characteristic of sticking, both in the roots, stems, and leaves of the vegetation that grows in the area as a form of migration due to the high sea level. The foraging activities in this species are active at night and the condition of the water is not in tidal conditions because of its nature as a scavenger.

In relation to maintain its survival, living things interact with the environment and tend to choose the best environmental conditions and habitat types to continue to 
grow and reproduce. The factors that influence the growth of shellfish are the season, temperature, salinity, substrate, food, and other water chemical factors that vary in each region. Measurement of physical-chemical parameters can describe the quality of the environment at a certain time. Besides, biological indicator measurements can monitor continuously and are easy instructions to monitor the occurrence of pollution. The physicalchemical factors of the waters in the study location are still below the threshold and are still within tolerance for the conditions of life and development of mollusks. Therefore, the diversity of mollusks in the research location can also be influenced by the physical-chemical factors of the waters.

\section{CONCLUSION}

As a conclusion related to the study conducted in Tutuwoto mangrove area of Anggrek district, North Gorontalo, it can be concluded that:

1. The abundance index of mollusks in Tutuwoto mangrove area in Anggrek Subdistrict, North Gorontalo District, shows different values for each species. The highest abundance index value is owned by Anadara granosa species with a value of $53.06 \%$, Mactra grandis species with a value of $46.94 \%$,
Nerita articulata species with a value of $30.41 \%$, Terebralia sulcata species with a value of $28.07 \%$, Hexaplex trunculus species with a value of $23.98 \%$ and the lowest owned by Terebralia palustris species with a value of $17.54 \%$.

2. The value of diversity index of mollusks in the Tutuwoto mangrove area of Anggrek District, North Gorontalo Regency shows that the spread of individual numbers per species and community instability is classified as in the moderate level. The diversity value index of Terebralia sulcata, Nerita articulata and Mactra grandis species has the same value namely $\mathrm{H} '=0.36$, Hexaplex trunculus and Anadara granosa species have $\mathrm{H}^{\prime}=$ 0.34, and Terebralia palustris species has a value of $H^{\prime}=0.31$.

3. The index of the density value of mollusks in the Tutuwoto mangrove area of Anggrek District, North Gorontalo Regency, shows different values for each species. The highest density index is owned by Anadara granosa species with a value of $53.1 \%$, Mactra grandis species with a value of $46.0 \%$, Nerita articulate species with a value of $30.4 \%$, Terebralia sulcata species with a 
value of $28.2 \%$, Hexaplex trunculus species with a value of $23.9 \%$ and the lowest owned by Terebralia palustris species with a value of $17.5 \%$.

\section{E. REFERENCES}

Arbi, U.Y. (2008). The Mollusk in the Mangrove Ecosystem in Tambak Wedi, Madura Strait, Surabaya, East Java. Oseanologi and Limnologi in Indonesia 34(3): 411425.

Bengen DG. (2001). The Introduction to Technical Guidelines and Mangrove Ecosystem Management. Bogor. The Center of Coastal and Ocean Resources Studies, Bogor Agricultural Institute, Bogor.

Brower, J.E., Jerrold H.Z., Car I.N.V.E. (1990). Field and laboratory methods for general ecology. third edition. Wm.C.Brown Publisher, USA, New York.

Dali, Rifal, (2018). The litter productivity and food chain models in Tutuwoto Mangrove Area of Anggrek District, North Gorontalo Regency. Thesis. Postgraduate Program of Population and Living Environment, Universitas Negeri Gorontalo.

Fitriyani, F., Yunasfi,. \& Desrita. (2016). The Production and Decomposition of Mangrove Leaves of Rhizophora stylosa in Pulau Sembilan Village of Pangkalan Susu Disctrict, Langkat Regency of North Sumatera. North Sumatera.

Retreived:
http://Users/Notebook/Downloads/ 15186-36364-1-SM.pdf.

Intan, Afrijal., T. Irvina, N. (2012). The Abudance of Anadara granos in the Costal water of Tanjung Balai, Asahan North Sumatra. Journal of Fisheries and Marine Sciences Faculty, Vo.1. No.1.Hal. 1-10.

KPH North Gorontalo. (2010). Mangrove Forest of North Gorontalo. Gorontalo

Latifah. A. 2011. The Morphology Characteristic of Anadara granosa. IPB. Bogor

Lisna, Malik Adam, Toknok Bau. 2017. The Potential Vegetation of Mangrove Forests in the Coastal Areas in Khatulistiwa Village of South Tinombo District, Parigi Moutong Regency. Foresty Faculty, Tadulako University. Central Sulawesi

Macintosh, DJ., Ashton, E.C. dan Havanon, S. (2002). Mangrove rehabilitation and intertidal biodiversity: A study in the Ranong Mangrove Ecosystem, Thailand. Estuarine, Coastal and Shelf Science

Michael, P. (1995). Ecology method for the Field Investigation and Laboratory. Indonesia University Press. Jakarta.

Nontji. A. (2006). No Life on Earth without the Presence of the Plankton. LIPI. Jakarta

Odum, Eugene P. (1996). Basic Ecology. 3rd Edition. Yogyakarta. Gadjah Mada University Press. Interpreter: Samingan. Tjahjono.

Sari, K.W., Yunasfi dan Suryanti, A. (2017). The Litter Decomposition of Mangrove Leaf Rhizophora 
apiculata in Bagan Asahan Village, Tanjungbalai District, Asahan Regency, North Sumatera Province. Acta Aquatica, 4(2): 88-94.

Wahyuni, Indria., Sari, Indah Juwita., Ekanara, Bambang. (2017). Biodiversitas Mollusca (Gastropoda Dan Bivalvia) as a Bio-Indicator of water quality in the coastal area of Tuna Island, Banten. Biology Education Program, FKIP, Untirta. Biodidaktika, Volume 12 No 2. 